\title{
THE TRANSMITTANCE OF PASSIVE SIDE OF THE OBLIGATIONAL REPORT IN THE VISION OF PROJECTS OF UNIFICATION OF LAW AT A EUROPEAN LEVEL, COMPARED WITH THE INTERNAL NORMATIVE DISPOSITIONS.

\author{
D. Deaconu-Dascălu
}

\author{
Diana Deaconu-Dascălu ${ }^{1}$ \\ Titu Maiorescu University \\ Faculty of Law and Economical Sciences, Tg. Jiu, Ecaterina Teodoroiu Street, no. 100, Romania \\ E- mail: http://www.accademiagiusprivatistieuropei.it/,diana.dascalu@gmail.com
}

\begin{abstract}
:
National civil law is reshaping its existence within the process of standardization of law at a European level, process that has begun at the end of the XX century and is in a permanent "maturation", having an obvious tendency towards adopting a unique legislation, proposing legal principles applicable to all member states. This study is about the main projects of Europeanization of law regarding the transmittance of debt, by comparing that with the internal normative dispositions.
\end{abstract}

\section{Keywords: cession of debt, debtor, creditor, European Civil Code, uniformization}

\section{Introduction}

Nowadays, although there is no such thing as a European Code within civil matters, compulsory for the member states, there are a series of projects that relate, as a result of research of scientific researches, academics and jurists of the member states of the European Union, existing thus a special concern towards the provisioning of the contractual laws.

Such projects, which mark the tendency of unification of the private law are: The Principles of the European Contract Law, presented by the Lando Commission, the Draft of European Code of Contracts (The Gandolfi Code, or the Padua Project), edited by the Academy of European Private Lawyers of Padua, the Project of the Common Reference Frame, proposed by the Study Group for a European Civil Code, the Commune and Contractual Terminology and the Commune Contractual Principles, elaborated by the Society of Compared Legislature and the Henri Capitant Association, the UNIDROIT Principles.

\section{European Contract Code}

The first project of European provisioning analyzed is the European Contract Code Project $^{1}$, known under the name of The Padua Project or the Gandolfi Code, from the name of its coordinator Giuseppe Gandolfi.

This project proposes a systemic approach, analyzing all three variants of assignment: the assignment of rights, the assignment of debt and the assignment of contract.

We will analyze, within this context, only one of the three types of assignment, namely the assignment of debt, which is presented within the contents of three articles: art. 125-127.

The creators of this project of Code do not grant any attention to the definition of this judicial instrument, but would rather make a straight forward presentation of the modalities in

\footnotetext{
${ }^{1}$ http://www.accademiagiusprivatistieuropei.it/
} 


\section{Deaconu-Dascălu}

which a debt may be transferred. Thus, article $125^{2}$ states that the transfer of a debt takes place in two ways: a. through the transfer consisting in the ,succession, when the obligation is transferred objectively intact to a third party who is joined to the original debtor or replaces the latter as indicated in Article 126", the obligational report remaining intact in what regards its object; b. „by conventional extinction of the original debt and the simultaneous setting-up of a new obligation with a different debtor", meaning through subjective novation.

Although the introductory text of the two modalities expressly refers to a "transfer" of a debt, we may observe that, in reality, only the first case allows a so-called transfer of debt, the second one (subjective novation) has an extinctive effect, to which it is attached the birth of a new obligation at the same time the old one is completed.

The first method of debt translation, regulated through article 125 of the Project refers to a translation of debt through "succession within the obligational report".

The term "succession", although used within internal legal language as a referral to the transmittance mortis causa of obligational reports, is used within this context with the signification of a conventional translation among living of an obligation sprung from a contractual report.

It regards the mechanism through which the new debtor inherits the old one within the obligational report. This method includes not only the possibility of the new debtor to inherit the old one, but also the possibility for the first to be held responsible along the initial debtor for the execution of the obligation.

The $2^{\text {nd }}$ paragraph of the same article strengthens the idea inserted by the $1^{\text {st }}$ paragraph, stating as a rule the solidarity among debtors, and as exception, the liberation of the initial debtor, a request that must have a previous agreement.

The $3^{\text {rd }}$ paragraph introduces a new rule, imposing, as a priority, the first method of transfer, specifying expressly that the subjective novation must be previously agreed upon and must be a result of the trilateral agreement of the initial debtor, claimer and subsequent or succedent debtor. In case of doubt, the same article institutes the presumption that the "assignment" has been made through succession.

The $5^{\text {th }}$ paragraph allows the assignment of debt to be performed by one or more debtors.

We appreciate that this article allows a total or partial assignment of debt, all debtors, both initial and subsequent, being held, as a rule, by a solidary obligation and not a divisible one.

Of course, parties may set through convention that the obligations between subsequent debtors to be divisible, and the obligation of the initial debtor to be subsidiary to the one of the new debtor, the first being liable only if the new debtor does not execute the assumed obligation.

Besides, there is an important difference between the provisions of the Code project and the dispositions of the Romanian legislature within the new Civil Code.

Thus the Romanian Civil code uses a different naming in what regards the transfer of debt, that of "overtaking of debt" rather than the "assignment of debt" used by the Gandolfi Code.

\footnotetext{
${ }^{2}$ Art. 125 - 1. There are two modes of assigning a debt: a) by succession, when the obligation is transferred objectively intact to a third party who is joined to the original debtor or replaces the latter as indicated in Article 126 below; b) by conventional extinction of the original debt and the simultaneous setting-up of a new obligation with a different debtor.

2. In the first of the cases in para. 1, the new debtor is bound in solido with the original debtor unless the creditor expressly releases the latter.

3. A novation occurs only if expressly and unambiguously agreed by the parties in their trilateral agreement. In case of doubt the assignment is presumed to be made by succession.

4. Apart from the provisions of paras. 2 and 3 of this Article, the parties can make the assignment of debt in the manner they consider most suited to their interests, for example as in Art. 126 below.

5. The debt can be assigned to one or more new debtors.

6. When the assignment occurs by operation of law or as an accessory of the transfer of goods or set of goods, the assignment is subject to the provisions of this section, as far as applicable, failing other specific rules.
} 
THE TRANSMITTANCE OF PASSIVE SIDE OF THE OBLIGATIONAL REPORT IN THE VISION OF PROJECTS OF UNIFICATION OF LAW AT A EUROPEAN LEVEL, COMPARED WITH THE INTERNAL NORMATIVE DISPOSITIONS

But it's not just the terminology that is different, but also the methods through which a translation of debt would be possible.

Thus, while the Gandolfi Code adds the subjective novation as a method to transmit the debt, although its main effect is extinctive, spreading to the accessories and warranties of the assigned debt, the Romanian Civil Code does not include novation in the methods of obligation transmission, but it resumes to the effective assignment of debt, through a contract perfected by the initial debtor and the subsequent debtor with the agreement of the creditor and by a contract perfected directly by the creditor and the new debtor.

Another difference resides in the nature of the obligations in the reports of the two debtors.

Thus, unlike the Gandolfi Code which institutes as a rule the solidarity of the two debtors, the Romanian Civil Code institutes as a rule the liberation of the initial debtor, as an effect of its replacement with the new debtor, with no mention to the nature of the obligational relationship specific to the imperfect claim taking over, meaning without the liberation of the debtor.

Critics proposed different methods: be it a solidary obligation or an obligation divisible amongst debtors, or the obligation of the initial debtor would be subsidiary to the obligation of the new debtor.

Another element of difference between the two provisions is presented in the absence of a mention within the Romanian Civil Code in what regards the possibility of debt taking over should produce towards more debtors (such a disposition is comprised within the $5^{\text {th }}$ point of article 125 of the Padua Project).

Although such a provisioning lacks, the Romanian legislator, using a singular form in what regards the party which would assume the debt, we appreciate that, within the principle of free will, nothing would impeach the parties to prefer that the claim taking-over should be done among more debtors, towards which the obligation would be solidary.

Another difference among the two provisions is introduced by point 6 of article 125 of the Padua Project. This text, on one hand, admits that the transfer of debt may intervene indirectly, in virtue of the law (the legal assignment of debt), or as an accessory element within the transfer of an asset or a transfer of assets, but, on the other hand, it admits that these types of transfers of debt are set under the dispositions of the present section, in lack of specific dispositions. Thus, the editors of the project set the present section as the commune provisioning in the matters of the transfer of rights, yet any specific dispositions may derogate from those comprised within the mentioned articles.

The national doctrine though, considered that the provisions of the Civil Code in the matter of debt assumption do not apply in the case of an assignment/assumption of debt ex lege or the case of an indirect debt assumption as a result of the assumption of an asset or perfection of an assignment of contract, but only in the case of the conventional debt assumption, and for all other above cases the specific provision of each operation apply.

Article 126 presents the mechanism through which "the assignment of debt" produces its effects.

Thus, through a convention of the debtor and a third party, the third party may engage towards the first party to complete the obligation completing the benefit to which the debtor engaged, but such an agreement produces only internal effects among the debtor and the third party.

Article 1599 of the Romanian Civil Code also has a similar disposition, stating, as a method of debt assumption, the contract perfected between a third party and the debtor, with the agreement of the creditor. It is though true that the national legislator did not assume the phrasing that would indicate that this contract "produces internal effects between the debtor and the third party", yet, the Romanian doctrine, taking into account the compared law, began to use 


\section{Deaconu-Dascălu}

the notion of "internal assumption of debt", to refer to effects that produce strictly in the report of the debtor and the third party.

The $2^{\text {nd }}$ paragraph of article 126 of the Padua Project repeats the already presented provisions of the $2^{\text {nd }}$ paragraph of article 126 from the same project, stating as a rule the passive solidarity among the initial debtor and the third party which would have the quality of debtor, in lack of a contrary stipulation from the creditor.

We already mentioned that the Romanian legislator preferred to inverse the rule with the exception, stipulating as a rule the liberation of the initial debtor, yet without establishing what is the relational obligation in case the creditor means to hold liable the initial debtor along the new one.

The $3^{\text {rd }}$ paragraph gives possibility to perfect such an agreement for the creditor and the third party, the latter being held to complete the obligation of the initial debtor, and, in lack of contrary stipulation, the creditor would hold the third party, which perfected along the initial debtor.

Although through this method of debt transfer, the initial debtor is excluded from the contract, which is perfected only by agreement of the creditor and the third party, it still has the possibility to oppose, annulling the mentioned agreement, as provisioned by article $126,3^{\text {rd }}$ paragraph.

The possibility mentioned by paragraph 3 offers a real "privilege" to the debtor, whom, although is not required to agree upon the validity of debt transfer through the convention between the creditor and the third party, may impeach the result of its effects, by opposing it.

In a different approach, the efficacy of the convention that compels the third party to pay the debt is affected by a negatory resolvent condition.

The main effect of the agreement between creditor and third parties is the transfer of debt towards the third party, the latter being liable in solidary, along the initial debtor, in lack of a contrary stipulation. Thus, if the debtor would oppose, this effect will not occur, if the rule provisioned by the $3^{\text {rd }}$ paragraph is applied, which would mean that the third party couldn't pay the creditor the debt owned by the first debtor.

Unlike inefficacity which applies to the assignment of debt in cases that the creditor did not agree (in this case, as stated above, producing internal effects, between the debtor and third party), in the case of inefficacity for debtor opposition to the assignment of debt through contract between creditor and third party, since the effect of transmission of a such contract would produce among the creditor and the third party, the inefficacity comes to eliminate this effect, although the contract remains valid.

Point 4 of article 126 introduces another method through which the transfer of debt may occur, namely by "compulsory preliminary convention followed by an act of successive transfer and thus, of disposition, of the claim". The convention and the successive act may be perfected by the creditor (through agreement with the third party) or by the initial debtor (through agreement with the third party), but, which, for efficacy, must receive the creditor's agreement.

The third party, as stated by point 5 , may be or may not be a debtor of the main debtor. If so, then the payment of debt will be claimed on the will of the latter to compensate the payment of its own debt. If it is not a debtor of the first debtor, it will have the right to be compensated, if there is no contrary convention, by reimbursement or indemnity, the payment made, from the initial debtor, which took advantage of the pay by having a debt covered with its own creditor.

Article 126 point 6 also refers to the subjective novation of debt, which occurs by tripartite agreement perfected by the creditor, debtor and third party.

The effects of debt assignment are provisioned by article 127 of the Project, which differentiates between the novation agreement, which would deplete an old debt, by giving birth simultaneously to a new one in the patrimony of the new debtor and the "transmission through succession", case in which the "new debtor may oppose the creditor the exceptions which originated with the old debtor". 
THE TRANSMITTANCE OF PASSIVE SIDE OF THE OBLIGATIONAL REPORT IN THE VISION OF PROJECTS OF UNIFICATION OF LAW AT A EUROPEAN LEVEL, COMPARED WITH THE INTERNAL NORMATIVE DISPOSITIONS

The Romanian Civil Code emphasizes an ascertainment, which, constitutes, in fact, a limitation of this rule, establishing that the new debtor will not be able to oppose the creditor "the compensation or any other personal exception of the initial debtor" and "nor any defense means established on the judicial report between the new debtor and the initial debtor, even if that report has been the determinant motif to assign".

In the case of liberation by the creditor of the initial debtor, the same article states that "warranties tied to the claim are completed, and by exception they remain valid, but only if those whom constituted them give their express consent in what regards their validation".

Again, the provisions of the Romanian Civil Code are embracing a different view compared to the provisions of the European Project, stating that the assumption of debt "has no effect on the existence of claim warranties, apart from the case when they cannot be separated from the debtor". Thus, article 1602 of the Romanian Civil Code, starting from the idea that debt assumption supposes, usually, a transfer of an unchanged debt, with all constituted accessories and warranties, limits the completion of the warranties to the situation in which they are tied to the debtor or, case being, if it regards the obligation of the fidejussor or the third party which constituted a warranty in order to create the claim and did not agree to the assumption.

The creditor which accepted the obligation of the third party - as the $2^{\text {nd }}$ paragraph states - cannot hold liable the initial debtor if, previously, it has not demanded an execution of the debt from the third party which agreed to the claim.

Therefore, even if it appears permanently within this Project, the rule of debtor solidarity, paragraph 2 of article 127 stipulates an order in which the two debtors are compelled to execute the contract, giving priority to the new debtor and, only in case of refusal, the creditor may ask payment from the second.

The above mentioned provision strains, somewhat, from the rule according to which a passive solidarity would assume the possibility of the creditor to satisfy in full the claim from any of its debtors, mainly its concern being the possibility to claim liabilities from the debtor that has most possibility of solvency, but with no limitation to an order of preference in the execution of the claim.

The Romanian Civil law, provisioning the matter of debt assumption, did not cover the reports that are created between the debtors, when the liberation of the initial debtor is not provided. Yet, a disposition that is similar to the one in the Project is mentioned within the matter of contract assignment, article 1318 Civil Code stating that "if the assignee is not liberated, the assigned contractor may claim liabilities from the latter when the assignor does not complete its obligations". Therefore, at the case of a contract assignment, the legislator establishes the order of preference to the execution of the contract, giving priority to the assignor debtor, and giving the assignee a subsidiary and conditioned liability, conditioned by the notification procedure, provisioned by article 1318 .

\section{The Project of the Principles of European Contract}

The second legal document submitted to analysis is the Project of the Principles of European Contract Law ${ }^{3}$, elaborated by the Committee for European contract law, also entitled the Lando Project (from professor Ole Lando, which chaired the Committee's works), being another major effort in the matter of standardizing the European legislature within civil matters, mostly the contract laws.

PECL provisions, same as Project Padua, all three types of assignment (claim, debt, contract), yet it dedicates an asymmetrical analysis, insisting especially upon the assignment of

\footnotetext{
${ }^{3}$ G. Rouhette, I de Lamberterie, D. Tallon, C. Witz, Principes du droit européen du contrat, coll. Droit privé comparé et européen, SLC, Paris, 2003
} 


\section{Deaconu-Dascălu}

claim (16 articles), but reminding only briefly, in two articles, the assignment of debt and in a single article, the assignment of contract.

As the assignment of claim and assignment of contract have separate chapters and sections, we will analyze, within this context, only the assignment of debt, as it has been regarded by the editors of Project Lando.

The assignment of debt is provisioned, as mentioned above, by two articles: 12:101 and 12:102 (French version).

The marginal name given to this operation does not coincide to the one found in Project Padua, which expressly stated the "assignment of debt", unlike the PECL which uses the formula "substitution of a new debtor".

Article 12:101 is dedicated to general provisions, establishing that "a third party may engage to substitute the debtor, with the agreement of the debtor or the creditor, the substituted debtor being liberated by its obligations" 4 .

We observe that the PECL text averts slightly from the one of the Padua Project, establishing primarily the rule of liberation of the initial debtor by its substitution with a new debtor, unlike the Padua Project, which stated as a rule that the first debtor could be held liable, both being held solidary liable to the payment of the debt.

Establishing this rule of debtor liberation, the analyzed legal system coincides with the provision chosen by the Romanian legislator, which, in the case of debt assumption, establishes that the initial debtor will be liberated if the creditor does not expressly state it understands to hold the latter liable to the payment of debt.

Yet, unlike the Romanian Civil Code, which excepts from the liberation of debtor rule the situation in which the new debtor was unsolvable at the date it assumed the debt, but the creditor consented to the assumption, with no knowledge of the situation (article 1601 Civil Code), PECL does not elaborate regarding such details, considering a sufficient provision the general rule of debtor liberation.

Paragraph 2 of article 12:101 provisions the possibility that the creditor would express an anticipated consent to the future substitution of its debtor, yet the substitution would not produce effects until the new debtor would have notified the agreement it perfected with the original debtor.

We observe that within this project too, the possibility for an anticipated consent is allowed, same as in Project Padua, and same as the Romanian Civil Code, compelling the parties, as to the moment the substitution would be perfected, to be the moment at which the creditor is notified regarding the substitution agreement. Yet, unlike the other two mentioned provisions, which allow the notification to be made by the new debtor or by the initial debtor, the notification, according to PECL, must be made, as expressly stated, by the new debtor, eliminating thus the initial debtor.

Article 12:1025 represents the main legal provision of effects which the substitution of debtor are applied to defense means and warranties, stipulating, as a rule, the fact that the new

\footnotetext{
${ }^{4}$ ARTICLE 12:101: SUBSTITUTION: DISPOSITIONS GÉNÉRALES

(1) Un tiers peut, avec l'accord du débiteur ou du créancier, s'engager à se substituer au débiteur, ce dernier étant délié de ses obligations.

(2) Le créancier peut consentir à l'avance à une substitution future. La substitution ne prend alors effet que lorsque le nouveau débiteur lui notifie l'accord qu'il a conclu avec le débiteur originel.

${ }^{5}$ ARTICLE 12:102: EFFETS DE LA SUBSTITUTION SUR LES MOYENS DE DÉFENSE ET LES GARANTIES

(1) Le nouveau débiteur ne peut invoquer à l'encontre du créancier aucun droit ni moyen de défense procédant de ses rapports avec le débiteur originel.

(2) La libération du débiteur originel s'étend aux garanties qu'il avait consenties au créancier pour sûreté de sa créance, à l'exception de celles qui portent sur un bien transféré au nouveau débiteur en vertu d'un acte qu'il a conclu avec le débiteur originel.

(3) La libération du débiteur originel s'étend aux garanties consenties pour sûreté de la créance par toute personne autre que le nouveau débiteur, à moins que cette personne consente à maintenir sa garantie au profit du créancier.

(4) Le nouveau débiteur est en droit d'opposer au créancier tout moyen de défense que le débiteur originel aurait pu opposer au créancier.
} 
debtor will not be allowed to oppose the creditor no right or defense mean resulted from its reports with the initial debtor. The new debtor, is in its right to oppose the creditor all defense means which the original debtor could have opposed the creditor.

The Romanian Civil Code comprises similar provisions regarding the effects of debt assumption over the defense means, establishing, through article 1603, that, "even if from the contract does not result differently, the new debtor may oppose its creditor all means of defense which the initial debtor could have", yet, "it may not oppose the creditor the means of defense established on the judicial report born between the new debtor and the initial debtor, even if the report has been the determining motif for the assumption". The internal dispositions limit however the sphere of means of defense which may be opposed by the new debtor, eliminating the possibility to oppose the compensation to the creditor or any other personal exception of the initial debtor.

In what regards the warranties, the $2^{\text {nd }}$ paragraph states that the liberation of the initial debtor extends over the warranties that have been consented to the creditor in order to insure the debt, except those perfected for an asset transferred to the new debtor based on a document settled with the initial debtor.

The Romanian Civil Code does not follow this rule, establishing a different one: "Assumption of debt has no effect upon the existence of debt warranties, other than whether they cannot be separated by the party of the debtor" (Article 1602 Civil Code).

Also, the liberation of the original debtor covers the consented warranties to insure the payment of the debt by any other person but the new debtor, except the case in which the person which constituted the warranty consents to maintain it in the benefit of the creditor.

A similar provisioning is found within the internal legislation, article 1602 of the Romanian Civil Code stipulating that "the obligation of the fidejussor or the third party that constituted a warranty in order to accomplish the claim will be annulled if these two parties did not consent to the assumption". 


\section{Deaconu-Dascălu}

\section{The Unidroit Principles 6}

Although the role of these principles was to regulate the relations of international commercial law, it also analyzes the three types of assignments (claim, debt and contract), establishing rules and principles applicable, being, although, a source of inspiration for the editors of the contemporary Romanian Civil Code.

Chapter 9 treats the problematic of the three types of assignment in three different sections, the second one provisioning the assignment of debt, being preceded by the assignment of claim (section 1) and followed by the assignment of contract (section 3).

The Unidroit Principles use the term of "assignment of debt" and not the "substitution of a new debtor" (PECL) nor the "assumption of debt" (which is the one adopted by the Romanian legislator).

The introduction is sudden, as the mentioned text, with no interest to defining the utilized notion, skips into presenting the methods through which the assignment of debt is possible.

Thus, article 9.2.1 establishes as methods of the assignment of an obligation to pay an amount of money or to execute another benefit from a party called initial debtor to another party (the new debtor): a. the convention born between the original debtor and the new debtor, under the reserve of the article 9.2.3 (only possible with consent of creditor) and b. the convention between the creditor and the new debtor by which the latter assumes the debt.

This article has been adopted by the Romanian legislator with a literary translation, namely article 1599 Romanian Civil Code.

In both cases, the assignment of debt may occur only if there is a consent of the assigned creditor, condition stipulated by article 9.2.3, for the case when a convention is perfected among the initial debtor and the new debtor with the value of an efficacy condition or a validity condition of the assignment convention, in the case when a contract is perfected between the creditor and the new debtor, by which the latter is compelled to the payment of the debt.

The lack of a provision regarding the party which may notify the creditor regarding the assignment has been completed by the editors of the Civil Code, which in article 1606 state that "anyone of the contractors may communicate to the creditor the assumption contract, demanding for an agreement".

This demand represents an element of differentiation from the assignment of claim, in the case of which it is not required to have consent of the assigned debtor in order to have a valid or efficacy assignment. The reason to impose such a demand is yet a simple one: if, in the case of the assignment of claim, the debtor may not be prejudiced by the change of the creditor party, party to which it has to pay the claim, in the case of assignment of debt, the creditor may be prejudiced by the fact that the new debtor may not present the necessary "warranties' to execute the obligation and therefore not have the trust of the creditor, it being presented, without its will, in the situation to not be able to recover the debt.

Article 9.2.4 introduces the possibility that the creditor should offer its consent in an anticipatory manner, case in which the assignment produces effects at the moment at which the assignment is notified to the creditor or the latter admits it.

We observe thusly that the Unidroit Principles do not state which of the party has to notify the creditor, allowing thus the initial debtor or the new debtor, unlike the provisions of PECL which state this obligation at the task of the new debtor (art. 12:101).

The notification is not required in the case when the creditor "acknowledges the assignment" which it consented to previously. There is no compulsory form that the acknowledgement should bear, giving the possibility to be a result from a statement of express acknowledgement or tacit acknowledgement acts, from which it should result, without a doubt, the fact that the creditor has knowledge of the perfection of the assignment convention.

\footnotetext{
${ }^{6}$ www.unidroit.org.
} 
THE TRANSMITTANCE OF PASSIVE SIDE OF THE OBLIGATIONAL REPORT IN THE VISION OF PROJECTS OF UNIFICATION OF LAW AT A EUROPEAN LEVEL, COMPARED WITH THE INTERNAL NORMATIVE DISPOSITIONS

The Romanian Civil Code does not comprise such dispositions in the matter of debt assumption, but there are similar provisions to the Unidroit Principles within the matter of contract assignment, article 1317 establishing that "if a party has consented in an anticipatory manner that the other party should be able to substitute a third within contractual reports, the assignment is valid towards that party from the moment the substitution has been notified, or, if the case, from the moment it is accepted".

In what regards the legal sphere to which it applies, section 2 of Chapter IV of the Unidroit Principles is applicable only to the conventional assignments of debt, and not to assignments of debt that appear by effect of law (IE those which appear from a corporate fusion) ${ }^{7}$ . Also, the provisioning of assignment of debt are applicable both in the case when the assigned debt has as a goal the obligation of payment of an amount of money, but also obligations that have as purpose different forms of benefit, as different services. The source of the obligations is not limited exclusively to debts of a contractual nature, but may also be of debts born from a new liability or an existing liability based on a legal decision.

In what regards the effects of the assignment of debt, article 9.2.5 allows the creditor to choose whether to liberate the initial debtor. If it chooses not to liberate the initial debtor, it is held as "warrant" for the situation in which the new debtor would not correctly execute its obligation. In this situation, the creditor must first hold liable the new debtor in order to receive the execution of the obligations, being able to hold the initial debtor liable only if the new one did not execute correctly. Therefore, the obligation to which the initial debtor could be held in this hypothesis is subsidiary.

The Romanian Civil Code does not comprise such a provision within the matter of debt assumption, but something similar is stipulated in the matter of contract assignment, article 1318 stating a subsidiary obligation of the assignee, the assigned having the possibility to hold it liable only in the case in which the assignor would not execute its obligations.

The creditor has yet another option, even better, the one to hold the initial debtor and also the new debtor in solidary liability, having the possibility to demand execution of the obligation from the both of them. If the obligation will be executed by the initial debtor, as a rule, the latter will have a regress right against the new debtor.

Whether the creditor did not state upon the liberation of the initial debtor, or if it wills to hold it as a subsidiary debtor, the rule to apply establishes that both will be solidary responsible to the execution of the assumed obligation ( $3^{\text {rd }}$ paragraph of article 9.2.5).

The Romanian Civil Code, although it somewhat presented in a similar manner provisions of the Unidroit Principles, it didn't follow the rule of debtor solidarity, which would intervene every time the creditor does not state whether it liberates or not the initial debtor. To that sense, article 1600 of the Civil Code states that "by perfection of the contract of debt assumption, the new debtor replaces the old debtor, which, if no other stipulation, and under reserve of dispositions of article 1601, is liberated".

From this rule, article 1601 of the Romanian Civil code introduces the exception that eliminates liberation of the initial debtor whether the new debtor is not solvable, if the creditor had no knowledge of that fact previous to its expressed consent.

Article 9.2.6 $6^{8}$ introduces the hypothesis of execution of the obligation by a third party, through a conventions perfected only between the debtor and a third party, with no consent from the creditor, or in the case in which the creditor would have already refused to agree to the assignment. Based on this convention, a third party compels to the debtor, to execute the

${ }^{7}$ To see art. 9.2.2 from the Unidroit Principles.

${ }^{8}$ ARTICLE 9.2.6 (Exécution par un tiers).

1) Sans le consentement du créancier, le débiteur peut convenir avec une autre personne que cette dernière exécutera l'obligation à la place du débiteur, à moins que l'obligation, selon les circonstances, ne revête un caractère essentiellement personnel.

2) Le créancier conserve son recours contre le débiteur. 


\section{Deaconu-Dascălu}

obligation on his behalf. Of course, such a convention cannot be valid if the obligation assumed by the debtor is a personal one, with a pronounced intuitu personae character. Such a convention, out of the range of influence of the creditor, may not remove the right of the creditor to demand and obtain an execution of the obligation from its debtor, as the obligational report it has with the debtor is in no manner altered by the convention intervened between the later and the third party. Yet, the creditor, as a principle, cannot refuse payment or execution of the obligation by another party but its debtor, with the limitation of an essentially personal obligation from its debtor.

In what regards the effects of the assignment, article 9.2.7 stipulates that "the new debtor may oppose the creditor all means of defense the initial debtor may have used", with no importance if they belong to the material law or the procedural law (certain clauses, exceptions etc.), yet it will not be able to invoke a compensation right which would have been at the disposal of the initial debtor against the creditor, as the demand of reciprocity is not met, requirement which is compulsory in order to have an operational compensation. The compensation could be invoked after the assignment of debt by the initial debtor if the latter had not been liberated.

This provisioning has been also chosen by the Romanian legislator, which presented it in a similar manner within article 1603 of the Civil code. This article is completed by the provisioning which states that the new debtor cannot oppose the creditor the means of defense established on the judicial report born among the new debtor and the previous debtor, even if that report had been the determining reason for the assumption.

In what regards the rights of the creditor ulterior to the assignment of debt, article 9.2.8 establishes the possibility of the creditor "to prevail in front of the new debtor of all payment rights or execution of another benefit, comprised within the contract, relative to the assigned debt".

If the assignment of debt is "perfect", having as effect the liberation of the initial debtor, the $2^{\text {nd }}$ paragraph of the same article provisions that "any party, other than the new debtor, which is a warrant of the payment, is liberated, except if the latter would accept to maintain the warranty in favor of the creditor."

Also, with the liberation of the initial debtor, the warranties given by the initial debtor are completed, except those which bear upon an asset transferred within an operation between the original debtor and the new debtor.

\section{Conclusions}

To conclude, visibly, the Romanian Civil Code presents provisions similar to those comprised within the projects of standardization in existence at a European level in civil matter, the contemporary legislator trying to include the modernization of the legislature within the circuit of European uniformization.

\section{Acknowledgments.}

This work was supported by the strategic grant POSDRU/159/1.5/S/141699, Project ID 141699, co-financed by the European Social Fund within the Sectorial Operational Program Human Resourses Development 2007-2013.

\section{References}

1. G. Rouhette, I de Lamberterie, D. Tallon, C. Witz, Principes du droit européen du contrat, coll. Droit privé comparé et européen, SLC, Paris, 2003.

2. http://www.accademiagiusprivatistieuropei.it/

3. www.unidroit.org 